Arq. Bras. Med. Vet. Zootec., v.70, n.4, p.1045-1052, 2018

\title{
Acoustic radiation force impulse elastography of the eyes of brachycephalic dogs
}

[Elastografia acoustic radiation force impulse dos olhos de cães braquicefálicos]

\author{
T.G.M. Abreu ${ }^{1}$, M.A.R. Feliciano ${ }^{1,2}$, R. Renzo ${ }^{1}$, K.K. Kobashigawa ${ }^{1}$, F.D.Y.C. Chacaltana ${ }^{1}$, \\ R.M. Crivelaro ${ }^{1}$, C.P. B. Silveira ${ }^{1}$, N.R.N. Cruz $^{1}$, M. Aldrovani ${ }^{1}$, M.C. Maronezi ${ }^{1}$, \\ P.A. Silva ${ }^{1}$, R. Thiesen ${ }^{3}$, J.L. Laus ${ }^{1}$ \\ ${ }^{1}$ Universidade Estadual Paulista - Jaboticabal, SP \\ ${ }^{2}$ Universidade Federal do Recôncavo da Bahia - Cruz das Almas, BA \\ ${ }^{3}$ Universidade Federal do Pampa - Uruguaiana, RS
}

\begin{abstract}
Eyes from brachycephalic dogs were studied by acoustic radiation force impulse (ARFI) elastography to establish quantitative and qualitative reference values related to the shape and rigidity of some ocular structures. Eighty-four eyes from 42 adult brachycephalic dogs were included in this study. Animals were subjected to physical, laboratory, and ophthalmic examinations. Following confirmation of good health, the dogs were subjected to ultrasonography and ARFI elastography, emphasizing the optic nerve, ciliary body, and lens. On qualitative elastography, homogeneous characteristics were observed on the ciliary body and optic nerve. Aqueous and vitreous humors were visualized as mosaic-like images. Quantitative elastography showed the mean optic nerve shear wave velocity (SWV) was $1.01 \pm 0.27 \mathrm{~m} / \mathrm{s}$, temporal ciliary body was $0.91 \pm 0.24 \mathrm{~m} / \mathrm{s}$, and nasal ciliary body was $0.91 \pm 0.3 \mathrm{~m} / \mathrm{s}$. The SWV of the lens values were out of range, this value was not detectable by this software. Elastography has proved to be a non-invasive procedure and feasible in dogs. The establishmentof the parameters of degree of rigidity of ocular structures will serve as a baseline for animals with eye disorders. Results may be extrapolated to primary research on the applicability of ARFI in the evaluation of ocular bulb in humans.
\end{abstract}

Keywords: canine, ocular structures, ultrasound

\section{RESUMO}

Estruturas oculares de cães braquicéfalos foram estudadas por elastografia acoustic radiation force impulse (ARFI) para estabelecer valores quantitativos e qualitativos de referência relacionados com a forma e a rigidez de algumas estruturas oculares. Foram avaliados 84 olhos de 42 cães braquicéfalos neste estudo. Os animais foram submetidos aos exames físico, laboratorial e aos exames oftalmológicos. Após a confirmação da sanidade dos pacientes, os cães foram submetidos à ultrassonografia e à elastografia ARFI, enfatizando-se o nervo óptico, o corpo ciliar e a lente. Para elastografia qualitativa, foram observadas características homogêneas no corpo ciliar e no nervo óptico. Os humores aquoso e vítreo foram visibilizados como imagens tipo mosaico. A elastografia quantitativa demonstrou velocidades de cisalhamento para nervo óptico de

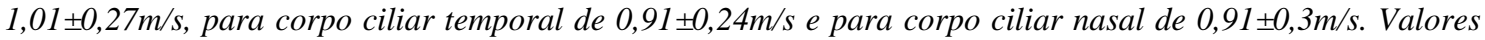
dessas velocidades para lentes apresentaram-se fora do intervalo: X.XXm/s. A elastografia provou ser um procedimento não invasivo e viável para cães. Estabelecidos os parâmetros do grau de rigidez das estruturas oculares, futuramente tais dados servirão como padrão para avaliação de animais com os distúrbios oculares. Os resultados podem ser extrapolados para a pesquisa primária sobre a aplicabilidade da ARFI na avaliação do bulbo ocular em seres humanos.

Palavras-chave: canino, estruturas oculares, ultrassom

Recebido em 7 de outubro de 2016

Aceito em 20 de abril de 2017

*Autor para correspondência (corresponding author)

Email: marcusfeliciano@yahoo.com.br 


\section{INTRODUCTION}

The ultrasound (US) elastography consists of a method capable of providing data related to the degree of rigidity of the tissues. The technique is based on the principle of elasticity, which is the capacity of a tissue to deform by mechanical compression and return to its original shape and size once the driving force is terminated. The higher the tissue rigidity, the lower the deformation capacity and the less time to return to its original state (Goddi et al. 2012).

Different types of elastography such as compression elastography, acoustic radiation force impulse (ARFI), and real-time shear velocity (RSV) are available (Dudea et al. 2011). They all permit evaluation of the shape and stiffness of structures, which is not feasible by palpation (Konofagou, 2004). The ARFI technique is safe and non-invasive, and it provides quantitative and qualitative measures of tissue rigidity with reduced interobserver variability compared with other diagnostic techniques (Dudea et al. 2011; Feliciano et al. 2014).

In qualitative ARFI, short acoustic pulses of high intensities are utilized to transiently deform the fragments of the tissue and create a greyscale static map or matrix (elastogram) representing the relative stiffness of the area of interest. In general, the lighter areas represent the more deformable tissues. Alternatively, the quantitative approach to ARFI utilizes a primary acoustic impulse sent towards a region of interest and promoting the formation of pressure waves capable of deforming the tissues to raise the speed of the wave propagation (shear velocity). The wave velocity and the attenuation of acoustic pressure waves are both related to the rigidity and viscoelasticity of the tissue; the waves have a greater velocity in rigid tissues (Comstock, 2011; Goddi et al. 2012).

In veterinary medicine, ARFI elastography is a method to be explored, since its application, to date, has been exclusively in scientific investigations. In domestic or laboratory animals, ARFI elastography was already used to evaluate prostatic and testicular tissue, for the differential diagnosis of mammary neoplasms and to evaluate hepatic, renal, and splenic parenquima (Feliciano et al., 2014; Holdsworth et al., 2014;
Feliciano et al., 2015; Maronezi et al., 2015). There are no reports of veterinary medicine on the use of elastography in ocular evaluation of patients.

Considering the recent applicability of ARFI method and the reports of this type of elastography in tissue evaluation of small animals, we hypothesize that it is feasible and applicable the accomplishment of the ocular elastography in dogs and the aims of this study were to assess, by ARFI elastography, injury-free eyes from brachycephalic breeds, and to determine qualitative and quantitative reference patterns.

\section{MATERIAL AND METHODS}

The Ethical Committee for Animal Use (CEUA) of the College of Agriculture and Veterinary Sciences, UNESP/Jaboticabal, approved the experimental design (protocol number 9516/15). Eighty-four eyes from 42 brachycephalic dogs (16 Shih Tzus, 11 English Bulldogs, 11 French Bulldogs and four Pugs); 21.43\% males and $78.57 \%$ females; $3.0 \pm 1.26$ years [range one to six years]) from private kennels were included in the study. Kennel owners signed a consent form allowing their dogs to be included in the study. The degree of kinship among the dogs was not considered part of the criteria for admitting or excluding them from the study.

Prior to admission, dogs were subjected to a complete physical examination, laboratory tests (complete blood count, alanine aminotransferase, and creatinine), and an ophthalmological examination (consensual and direct pupillary light reflex, menace response, Schirmer's tear test, slit lamp examination, applanation tonometry, binocular indirect ophthalmoscopy, fluorescein test, tears break-up time, and A and B mode ocular US). Following confirmation of good health, the dogs were subjected to ophthalmic elastography.

The US and elastography examinations were performed under physical restraint, and the corneal surface was desensitized with the topical anesthetic proxymetacaine $0.5 \%$ (Anestalcon, Alcon, Sao Paulo, Brazil). Sterile acoustic jelly (Supra Gel, AdlinPlasticos LTDA, Jaraguá do Sul, Brazil) was used as a coupling medium by the transcorneal method. 
A and B mode ocular US were performed using Ultrascan A/B Alcon (Alcon Laboratories, Texas, USA) at $20 \mathrm{MHz}$ in an axial position. Biometric parameters were evaluated (diameter, length, and thickness, in $\mathrm{mm}$ ), and the echogenicity and echotexture of the anterior, posterior, and vitreous chambers, lenses and of the retina-choroid-sclera (RCS) complex were measured. Images obtained were printed on thermal sensitive paper (Mitsubishi K-65HM, Tokyo, Japan) and analyzed by a team of veterinary ophthalmologists.

Ocular elastography was performed using ACUSON S2000/Siemens (Siemens; Munich, Germany) and the ARFI method, using a $9.0 \mathrm{MHz}$ transducer, always by the same examiner (sonographer experienced) (Feliciano et al., 2014). For qualitative studies, images were obtained in shades of gray, providing information about the rigidity of the structures assessed by conventional US, except the optic nerve and ciliary body, paying attention to tissue homogeneity conditions. In the quantitative method, shear wave velocity (SWV) $(\mathrm{m} / \mathrm{s})$ values from the optic nerve, temporal and nasal ciliary bodies, and lens were obtained as an average of three subsequent measurements. The range of SWV was $0-9 \mathrm{~m} / \mathrm{s}$ by the manufacturer's algorithm. Value beyond this range was displayed as X.XXm/s.

The number of participants needed to achieve study objectives was calculated using the standard deviation value previously obtained of optic nerve, with a 95\% confidence interval (Detorakis et al., 2010). US and ARFI elastography data were analyzed using descriptive statistics to establish the characteristic variability of a data set (biometric parameters by US, and rigidity by ARFI elastography) for the studied structures. Results are presented as minimum and maximum values (range), and as mean \pm SD using a 95\% confidence interval (95\% CI). Quantitative variables obtained from the right and left eyes were analyzed using an unpaired t-test. Correlations were conducted between the shear velocity obtained for optic nerve and ciliary body in the temporal and nasal region with the age groups of the animals, intraocular pressure (IOP), lens thickness and anterior chamber length. Correlations were evaluated using the Pearson and linear regression. Values were considered statistically significant when $\mathrm{P} \leq 0.05$. The MedCalc (Mariakerke, Belgium) software program was used for all analyses.

\section{RESULTS}

Conventional US imaging of ocular structures resulted in reproducible findings in all dogs examined in this study. Ocular biometry parameter measurements, obtained by conventional A mode US, for all brachycephalic dog breeds studied were $19.52 \pm 1.99 \mathrm{~mm}$ (range: $16.38 \mathrm{~mm}$ to $22.25 \mathrm{~mm}$; $95 \%$ CI: $19.25 \mathrm{~mm}$ to $3.22 \mathrm{~mm}$ ) for horizontal ocular diameter, $3.06 \pm 0.73 \mathrm{~mm}$ (range: $1.48 \mathrm{~mm}$ to $5.60 \mathrm{~mm}$; $95 \%$ CI: $2.90 \mathrm{~mm}$ to $3.22 \mathrm{~mm}$ ) for anterior chamber length, $9.50 \pm 0.46 \mathrm{~mm}$ (range: $8.28 \mathrm{~mm}$ to 10.91 $\mathrm{mm}$; $95 \% \mathrm{CI}: 9.39 \mathrm{~mm}$ to $9.60 \mathrm{~mm}$ ) for vitreous chamber length, and 6.93 $\pm 0.71 \mathrm{~mm}$ (range: $4.17 \mathrm{~mm}$ to $8.10 \mathrm{~mm}$; $95 \%$ CI $6.78 \mathrm{~mm}$ to $7.09 \mathrm{~mm}$ ) for lens thickness. There was no significant difference between the right and left eyes for these parameters $(\mathrm{P}>0.05)$.

Aqueous and vitreous humor located before and after the lens, respectively, of all eyes assessed by $\mathrm{B}$ mode US presented as anechoic images with homogeneous echotexture. Anterior and posterior lens capsules presented as curvilinear images (convex and concave, respectively) and showed a hyperechoic pattern. The lens itself presented homogeneous echotexture, with an anechoic pattern. The retina-choroid-sclera complex was visualized as a unique and hyperechoic structure, delimiting the posterior region of the eye globe. The optic nerve was hypoechoic, caudally to the optic disk.

Elastography was performed in all individuals dispensing the sedation. Qualitative ARFI elastography evaluations (Figure 1a and 1b) revealed that anterior and posterior lens capsules are more rigid than other assessed structures, presenting as homogeneous images, in a dark gray shade. The lens was observed as a heterogenic image, with alternation of dark and light gray areas, similar to a mosaic. The same pattern was observed on aqueous and vitreous humor. The optic nerve and ciliary body were seen as homogeneous images, with the first one having a dark gray shade, and the second one medium gray. 


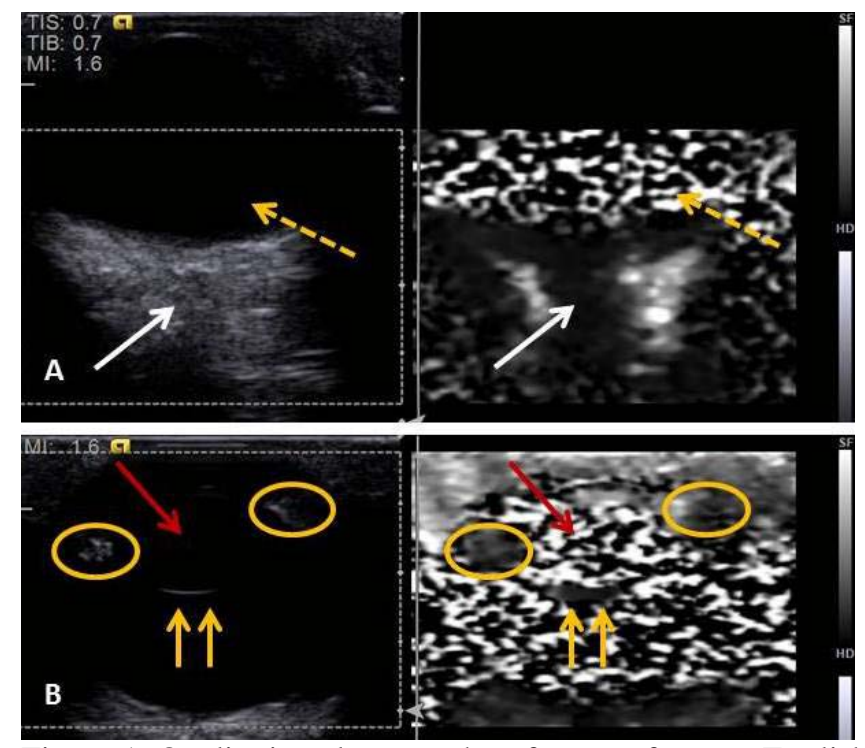

Figure 1. Qualitative elastography of an eye from an English Bulldog, showing (A) the optic nerve (white arrows) that appears homogeneous, with a dark gray coloring, and vitreous humor (interrupted yellow arrows) appearing heterogeneous, with light and dark gray areas (mosaic). (B) The aspects of the posterior lens capsule (continuous yellow arrows) in a homogeneous pattern of dark gray coloring, and the lens (red arrow) appearing heterogeneous (mosaic), consisting of dark and light gray areas. The ciliary body (yellow circle) looks homogeneous, with a medium gray coloring.

ARFI elastography images provided details that conventional US did not show, especially tissue characteristics of the structures evaluated. The ciliary body, which was almost not seen with conventional US, could be visualized and characterized by elastography.

Figure 2a to $2 \mathrm{~d}$ shows the results of the elastography quantitative method. The mean
SWV values for the eyes of all studied breeds were $1.01 \pm 0.27 \mathrm{~m} / \mathrm{s}$ (range: $0.57 \mathrm{~m} / \mathrm{s}$ to $1.91 \mathrm{~m} / \mathrm{s}$; $95 \%$ CI: $0.96 \mathrm{~m} / \mathrm{s}$ to $1.07 \mathrm{~m} / \mathrm{s}$ ) for the optic nerve, $0.91 \pm 0.24 \mathrm{~m} / \mathrm{s}$ (range: $0.53 \mathrm{~m} / \mathrm{s}$ to $1.75 \mathrm{~m} / \mathrm{s} ; 95 \%$ CI: $0.86 \mathrm{~m} / \mathrm{s}$ to $0.97 \mathrm{~m} / \mathrm{s}$ ) for the temporal ciliary body, $0.91 \pm 0.3 \mathrm{~m} / \mathrm{s}$ (range: $0.51 \mathrm{~m} / \mathrm{s}$ to $1.91 \mathrm{~m} / \mathrm{s}$; $95 \%$ CI: $0.84 \mathrm{~m} / \mathrm{s}$ to $0.97 \mathrm{~m} / \mathrm{s}$ ) for the nasal ciliary body, and XX.Xm/s (out of range values) for the lens.
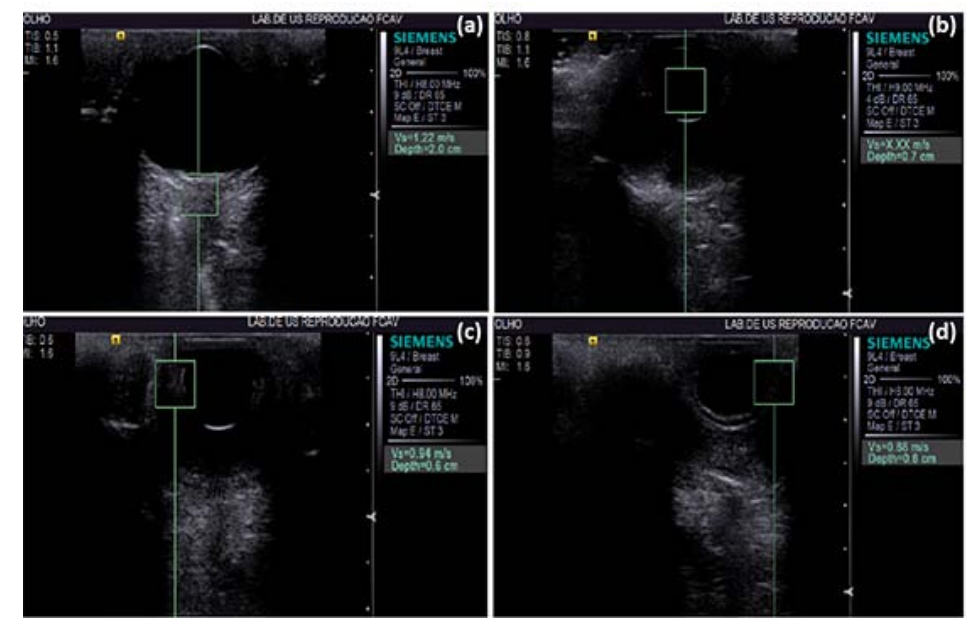

Figure 2. Acoustic radiation force impulse elastography of the right eye from a French Bulldog, showing the degree of stiffness (mm/s) of the optic nerve (A), lens (B), nasal ciliary body (C), and temporal ciliary body (D). 
Variables statistically related to the SWVs obtained for the optic nerve and ciliary body for each breed studied are summarized in Tab. 1.
There were no statistically significant differences between the right and left eyes $(\mathrm{P}>0.05)$.

Table 1. Values for shear wave velocity (SWV) of ocular structures in brachycephalic dogs optic nerve (ON), temporal ciliary body (TCB), and nasal ciliary body (NCB)

\begin{tabular}{|c|c|c|c|c|c|c|}
\hline $\mathrm{SWV} \mathrm{m} / \mathrm{s}$ & Minimum & Maximum & Mean & Standard deviation & Min 95\% CI & Max 95\% CI \\
\hline & \multicolumn{6}{|c|}{ Shih Tzu } \\
\hline ON & 0.57 & 1.47 & 0.95 & 0.21 & 0.87 & 1.02 \\
\hline TCB & 0.62 & 1.75 & 1.03 & 0.25 & 0.94 & 1.12 \\
\hline \multirow[t]{2}{*}{ NCB } & 0.59 & 1.91 & 0.98 & 0.32 & 0.87 & 1.10 \\
\hline & \multicolumn{6}{|c|}{ English Bulldog } \\
\hline ON & 0.70 & 1.63 & 1.02 & 0.24 & 0.92 & 1.13 \\
\hline TCB & 0.57 & 1.32 & 0.84 & 0.21 & 0.75 & 0.94 \\
\hline \multirow[t]{2}{*}{ NCB } & 0.51 & 1.87 & 0.88 & 0.35 & 0.72 & 1.03 \\
\hline & \multicolumn{6}{|c|}{ French Bulldog } \\
\hline $\mathrm{ON}$ & 0.58 & 1.79 & 1.05 & 0.33 & 0.90 & 1.20 \\
\hline ТCB & 0.53 & 1.28 & 0.78 & 0.21 & 0.69 & 0.88 \\
\hline \multirow[t]{2}{*}{ NCB } & 0.58 & 1.53 & 0.85 & 0.26 & 0.73 & 0.96 \\
\hline & \multicolumn{6}{|c|}{ Pug } \\
\hline $\mathrm{ON}$ & 0.91 & 1.17 & 1.17 & 0.32 & 0.90 & 1.44 \\
\hline TCB & 0.79 & 1.21 & 0.99 & 0.12 & 0.89 & 1.10 \\
\hline NCB & 0.59 & 1.11 & 0.85 & 0.21 & 0.66 & 1.03 \\
\hline
\end{tabular}

The SWVs for optic nerve showed significant correlation both with IOP $(\mathrm{R}=0.241 ; 95 \% \mathrm{CI}$ : 0.029 to $0.443 ; \mathrm{P}=0.02$ ) and lens thickness $(\mathrm{R}=0.291 ; 95 \%$ CI: 0.082 to $0.476 ; \mathrm{P}=0.00)$. No significant correlations were observed between the SWVs and the patient's ages or the measurements of ocular length (axial, anterior, and vitreous chambers) provided by the ocular US ( $\mathrm{P}>0.05$ for all).

\section{DISCUSSION}

The ocular biometry values found in the current study are consistent with previous studies, confirming that the eyes studied were healthy (Srinivasan et al., 2004). Ocular US biometry values, obtained by conventional A mode US, including axial length of the eye, anterior chamber length, vitreous chamber length and lens thickness, were already reported in other studies involving Shih Tzu and other brachycephalic breeds (Samuelson, 2007; Mattoon and MacKay, 2015; Packer et al., 2015).

Quantitative and qualitative elastography patterns were established for the eye globes of healthy brachycephalic dogs with little variation in their results $(\mathrm{P}>0.05)$ (values for the structures shear velocity were constant between the animals and evaluated breeds). The results obtained are unprecedented, because to our knowledge, there are no data available about the use of ophthalmologic ARFI elastography in veterinary medicine. Additionally, this method has important characteristics such as obtaining results in real time, being dynamic, quick, and non-invasive, and dispensing with the use of sedative or general anesthetic.

The organization and macromolecular composition of ocular structures, especially the ones with a dense extracellular matrix, are modified by pathological events that affect tissue elasticity and rigidity before showing anatomical or biometrical alterations detectable by conventional US (Jacques, 2013). Studies about ocular biomechanics have contributed to the understanding of mechanisms associated with the pathogenesis of some injuries, such as optic nerve neuropathy, cataracts, glaucoma, retinal detachment, macular degeneration, and corneal alterations (Paszek et al., 2005; Urs et al., 2014). In context, we consider that this study provides important reference values for diagnostic image examinations, based on elasticity principles. 
In medicine, there are few medical reports about ocular elastography and previous studies have shown that the eye is the most heterogeneous organic tissue, for example the heterogeneity of the vitreous chamber, the increase of elasticity of the posterior chamber by the presence of an aqueous humor, and the degree of rigidity of ocular muscles during contraction and relaxation (Detorakis, 2010; Nightingale, 2011). In the present study, ocular structures were equally heterogeneous and qualitative elastography was effective in assessing rigidity parameters of the ciliary body, optic nerve, and lens. We emphasize that the information obtained in this study about the lens, and aqueous and vitreous humor heterogeneity is very important, considering that which are difficultly perceptible with conventional US (Mattoon and MacKay, 2015).

Besides providing information about stiffness, ocular qualitative elastography enables a detailed assessment about morphology and structural composition, which is more information than conventional US provides. Previous studies showed that ARFI qualitative elastography can detect minimal echogenicity and echotexture changes, and can define the borders of neoplasms of many organic tissues better than other US methods (Khorramshahi et al., 2007; Săftoiu et al., 2007; Feliciano et al., 2014; Feliciano et al., 2015).

Ciliary muscles are responsible for lens accommodation by relaxing and contracting their fibers (Khorramshahi et al., 2007; Săftoiu et al., 2007). In this study, the ciliary body was observed in medium gray shades on a qualitative elastography examination and in lower tissue velocity, when compared to the lens. The values provided for ciliary body reveals a possible clinical application of ARFI in the study of chronic uveitis that result in fibrosis or ciliary body atrophy reducing aqueous humor production and intraocular pressure (Gelatt, 2003).

The lens consists of long and thin fibers coated by a thick hyaline capsule, especially on its anterior part, and mainly of proteins, suggesting a solid characteristic which was confirmed by the stiffness characteristic verified this study (Stafford, 2001).
The SWV measurements of the lens produced non-numeric results, expressed as $X . X X \mathrm{~m} / \mathrm{s}$. There are two hypotheses to explain these values. The first one would be the low quality of the exam, that could have occurred because of the difficulty to generate and propagate the shear waves in the lens, by the presence of acoustic shadow or interferences related to patient's respiratory movement during sampling, which perturbs wave propagation (Bai et al., 2012). In unsuccessful cases, the equipment will retake some values, while with extremely high SWV values, the X.XX $\mathrm{m} / \mathrm{s}$ values will stand. (Wojcinski et al., 2013). The second hypothesis is that the lenses are extremely rigid structures and, therefore, the SWV values would be above the upper limit detectable by the equipment. (Bai et al., 2012). This response was reported in studies with breast masses in women, that showed values that exceeded upper limits due to their elevated heterogeneity and rigidity. (Bai et al., 2012; Wojcinski et al., 2013). Considering the quality of the exam when performing SWV measurements for structures like ciliary body and optic nerve, and also considering that respiratory movements did not interfere on these samplings, our attribution that the $\mathrm{X} . \mathrm{XX} \mathrm{m} / \mathrm{s}$ lens value is related to values over $9 \mathrm{~m} / \mathrm{s}$ can be justified. Moreover, the SWV sampling was performed three consecutive times to all structures, obtaining the same values $(\mathrm{X} . \mathrm{XX} \mathrm{m} / \mathrm{s}$ ) for the lens every time.

Corroborating, the lens SWV (X.XX m/s), seen on quantitative elastography in the current study, revealed that this structure has a high degree of stiffness, and can be classified as the most rigid one in dogs' globes. Considering that the cataracts develop structural changes in the lens, it is assumed that these biomechanical changes in canine patients with cataract also result in changes related to the rigidity of the lens (Laus, 2007; Galego et al., 2012). In the future, these abnormalities can be assessed by ARFI, since the present study defines parameters for normal stiffness of the lens.

In normal dogs, vitreous humor is composed of water, hyaluronic acid, and collagen fibers which gives the tissue biomechanical properties related to different degrees of rigidity (Frandson et al., 2005). This justifies the heterogeneous elastography pattern (mosaic) found in the current study. 
The ocular fundus and optic nervous were visualized as a dark gray shade and findings correspond to the composition and elasticity of this structure, where the macromolecular organization involved loose tissue coated by meninges (Dyce et al., 1997).

Besides serving as a predictive marker for different morbidities, it seems to be promising for diagnosis and prognosis. The technique offers information that is complementary to data obtained by conventional ophthalmic US, which has a comparable pattern that is highly valuable.

The number of animals may have been too small to reveal correlation between ophthalmic parameters and quantitative elastography data; however, the sample size was robust enough to demonstrate positive correlation between SWV to optic nerve and IOP. The same was observed between SWV to optic nerve and lens thickness. It was observed that the values obtained for SWV of the optic nerve showed a positive and significant correlation with the IOP values. Dog breeds with higher IOP values (in the normal range) had optic nerves that are more rigid. Moreover, it is expected that dogs presenting large and more stiffness optical discs consequently also have thicker lens, thus justifying the positive correlation between SWV values of the optic nerve and lens thickness (Squazoni, 2011).

At the moment, it is difficult to establish associations between these findings (morphophysiology and ocular homeostasis), since research in elastography is scarce and recent. IOP generates mechanical forces in the cribriform plate, which induces an increase of crosslinks number between collagen molecules, increasing the tissue stiffness.

Taking into consideration that the elastographic method detects biomechanical abnormalities of the optic nerve associated with subtle differences and breed-specific IOP, perhaps it may be a predictive tool for the detection of pathological changes associated with ocular blood flow disturbances and chronic elevation of IOP. The ability to monitor elasticity parameters in ocular tissues and correlate them with changes in IOP and pathological changes in the optic nerve is a growing trend that has been defended by several authors (Thornton et al., 2009).

\section{CONCLUSION}

With the establishment of the biomechanical parameters of some ocular structures of eyes from brachycephalic breeds by ARFI elastography, we hope that this study contributes to future research related to the diagnosis and therapeutic monitoring of different eye diseases mainly regarding the lens, ciliary body, and optical nerve.

\section{ACKNOWLEDGEMENTS}

The authors thank São Paulo Research Foundation (FAPESP; process numbers 2015/13225-6 and 2012/16635-2), National Council of Technological and Scientific Development (CNPq-00833/2010-5), the Coordination for the Improvement of Higher Education Personnel (CAPES), and the kennel owners who supported this research.

\section{REFERENCES}

BAI, M.; DU, L.; GU, J. et al. Virtual touch tissue quantification using acoustic radiation force impulse technology: initial clinical experience with solid breast masses. J. Ultrasound Med., v.31, p.289-294, 2012.

COMSTOCK, C. Ultrasound elastography of breast lesions. Ultrasound Clin., v.6, p.407-415, 2011.

DETORAKIS, E.T.; DRAKONAKI, E.E.; TSILIMBARIS, M.K. et al. Real-time ultrasound elastographic imaging of ocular and periocular tissues: a feasibility study. Ophthal. Surg. Lasers Imaging, v.41, p.135-141, 2010.

DUDEA, S.M.; GIURGIU, C.R.; DUMITRIU, D. et al. Value of ultrasound elastography in the diagnosis and management of prostate carcinoma. Med. Ultrasound, v.13, p.45-53, 2011.

DYCE, K.M.; SACK, W.O.; WENSING, C.J.G. (Eds.). Tratado de anatomia veterinária. 2.ed. Rio de Janeiro: Guanabara Koogan, 1997. 663p.

FELICIANO, M.A.R.; MARONEZI, M.C.; PAVAN, L. et al. ARFI elastography as complementary diagnostic method of mammary neoplasm in female dogs - preliminary results. J. Small Anim. Pract., v.55, p.504-508, 2014.

FELICIANO, M.A.R.; MARONEZI, M.C.; SIMÕES, A.P.R. et al. Acoustic radiation force impulse elastography of prostate and testes hefalthy dogs: preliminary results. J. Small Anim. Pract., v.56, p.320324, 2015. 
FRANDSON, R.D.; WILKE, W.L.; FAILS, A.D. (Eds.). Anatomia e fisiologia dos animais de fazenda. 6.ed. Rio de Janeiro: Guanabara Koogan, 2005. 454p.

GALEGO, M.P.; SAFATLE, A.M.V.; OTSUKI, D. et al. Comparison of anterior ocular segment structures in healthy dogs, with diabetic or no diabetic cataract, by ultrasound biomicroscopy. Pesqui. Vet. Bras., v.32, p.66-71, 2012.

GELATT, K.N. Manual de oftalmologia veterinária. São Paulo: Manole, 2003. 594p.

GODDI. A.; BONARDI, M.; ALESSI, S. Breast elastography: a literature review. J. Ultrasound, v.15, p.192-198, 2012.

HOLDSWORTH, A.; BRADLEY, K.; BIRCH, S. et al. Elastography of the normal canine liver, spleen and kidneys. Vet. Radiol. Ultrasound, v.55, p.620-627, 2014.

JACQUES, S.L. Optical properties of biological tissues: a review. Physiol. Med. Biol., v.58, p.37-61, 2013.

KHORRAMSHAHI, O.; SCHARTAU, J.M.; KROGER, R.H.H. A complex system of ligaments and a muscle keep the crystalline lens in place in the eyes of bony fishes (teleosts). Vis. Res., v.48, p.15031508, 2008.

KONOFAGOU, E.E. Quo vadis elasticity imaging? Ultrasonics, v.42, p.331-336, 2004.

LAUS, J.L. Cirurgia del cristalino. In: HERRERA, D. (Ed.). Oftalmología clínica en animales de compañia. Buenos Aires: Inter-Médica, 2007.

MARONEZI, M.C.; FELICIANO, M.A.R.; CRIVELLENTI, L.Z. et al. Acoustic radiation force impulse elastography of the spleen in healthy dogs of different ages. J. Small Anim. Pract., v.7, p.99-110, 2015.

MATTOON, J.S.; MACKAY, C.S. Eye. In: MATTOON, J.S.; NYLAND, T.G. (Eds.). Small animal diagnostic ultrasound. 3.ed. St Louis: Copyright Elsevier Saunders, 2015. p.130-131.

NIGHTINGALE, K. Acoustic radiation force impulse (ARFI) imaging: a review. Curr. Med. Imag. Rev., v.7, p.328-339, 2011.
PACKER, R.M.A.; HENDRICKS, A.; BURN, C.C. Impact of facial conformation on canine health: corneal ulceration. Plos ONE, v.10, p.e0123827, 2015.

PASZEK, M.J.; ZAHIR, N.; JOHNSON, K.R. et al. Tensional homeostasis and the malignant phenotype. Cancer Cell, v.8, p.241-254, 2005.

SĂFTOIU, A.; GHEONEA, D.I.; CIUREA, T. Huehistogram analysis of real-time elastography images for noninvasive assessment of liver fibrosis. Am. J. Roentgenol., v.189, p.232-233, 2007.

SAMUELSON, D.A. Ophthalmic anatomy. In: GELATT, K.N. (Ed.). Veterinary ophthalmology. 4.ed. Iowa: Blackwell Publishing, 2007. p.47-107.

SQUAZONI, R. Biometria ocular e sua correlação com sexo, idade, tamanho e peso em cães da raça Cavalier King Charles Spaniel. 2011. 96f. Tese (Doutorado em Clínica Cirúrgica) - Faculdade de Medicina Veterinária e Zootecnia da Universidade de São Paulo. São Paulo, SP.

SRINIVASAN, S.; KROUSKOP, T.; OPHIR, J. A quantitative comparison of modulus images obtained using nano indentation with strain elastograms. Ultrasound Med. Biol., v.30, p.899-914, 2004.

STAFFORD, M.J. The histology and biology of the lens. Optom. Today, p.23-29, 2001.

THORNTON, I.L.; DUPPS, W.J.; ROY, A.S. et al. Biomechanical effects of intraocular pressure elevation on optic nerve/lamina cribrosa before and after peripapillary scleral collagen cross-linking. Invest. Ophthalmol. Vis. Sci., v.50, p.1227-1233, 2009.

URS, R.; LLOYD, H.O.; SILVERMAN, R.H. Acoustic radiation force for noninvasive evaluation of corneal biomechanical changes induced by crosslinking therapy. J. Ultrasound Med., v.33, p.14171426, 2014.

WOJCINSKI, S.; BRANDHORST, K.; SADIGH, G. et al. Acoustic radiation force impulse imaging with Virtual Touch ${ }^{\mathrm{TM}}$ tissue quantification: mean shear wave velocity of malignant and benign breast masses. Int. J. Women. Health, v.5, p.619-627, 2013. 